PASAR SEGAR BINTARO

\title{
SEBAGAI PASAR TRADISIONAL YANG DIKEMAS SECARA MODERN TEMPAT JUAL BELI PANGAN DI KELURAHAN PONDOK JAGUNG
}

\author{
Nisa Sabrina Geldin Gerung \\ Nisasgg.education@gmail.com \\ Mahasiswa Pendidikan Sejarah \\ Universitas Sultan Ageng Tirtayasa \\ September 2018
}

\section{PENDAHULUAN}

Pada tahun 2018 ini kita banyak menemukan berbagai macam bentuk pasarpasar modern yang bertebaran di pinggir jalan. Baik dalam ukuran semacam minimarket seperti Alfamart dan Indomart maupun supermarket-supermarket seperti Carefour, Giant, dan Hero. Menurut Direktorat Bina Pasar dan Distribusi Ditjen Perdagangan Dalam Negeri, Pasar adalah tempat bertemunya pihak penjual dan pihak pembeli untuk melaksanakan transaksi dimana proses jual beli terbentuk. Pasar-pasar ini baik yang berbentuk tradisional maupun modern merupakan wadah tempat jual beli pangan untuk masyarakat sekitar, dimana kualitas suatu pangan juga ditentukan dari tempat pemasarannya itu sendiri. Tapi yang patut kita ketahui bahwa masyarakat sekarang mulai lebih banyak membeli barang-barang keperluan sehari-hari khususnya pangan di pasar-pasar modern yang kebanyakan dimiliki oleh perusahaan asing. Termasuk di dalamnya ada berbagai macam produk pangan asing, yang berarti masyarakat lebih banyak membeli produk asing sedangkan pemerintah sedang berusaha menghidupkan rasa cinta masyarakat terhadap produk dalam negeri. Salah satu cara penyelesaian masalah ini yaitu dengan menghidupkan kembali kegemaran masyarakat berbelanja di pasar tradisional. Di Banten khususnya Tangerang Selatan terdapat banyak pasar tradisional salah satunya adalah Pasar Segar Bintaro yang merupakan pasar Tradisional yang dikemas secara modern.

Makalah ini akan membahas geohistoris dari kota Tanggerang Selatan, kegunaan dari Pasar Segar Bintaro serta perbandingan Pasar Segar Bintaro dengan 
pasar tradisional normal lainnya. Tujuan dibuatnya makalah ini adalah untuk membahas lebih lanjut berkaitan dengan eksistensi pasar khususnya Pasar Segar Bintaro sebagai tempat jua beli pangan masyarakat di kelurahan Pondok Jagung.

\section{PEMBAHASAN}

\section{Geohistoris Kota Tangerang Selatan}

Kota Tangerang Selatan merupakan kota termuda yang resmi memisahkan diri sejak tahun 2008 dari Kabupaten Tangerang, terletak di bagian Timur Propinsi Banten yang secara geografis berada diantara 6 $39^{\prime}$ - 6 6 $47^{\prime}$ ' Lintang Selatan dan 106 14 '- $106^{\circ} 22^{\prime}$ Bujur Timur dengan luas wilayah 147,19 kilometer persegi $\left(\mathrm{km}^{2}\right)$ atau sebesar 1,63 persen dari luas wilayah Provinsi Banten. Sedangkan secara administratif, Kota Tangerang Selatan terdiri dari 7 kecamatan, dan 54 kelurahan.

Wilayah Kota Tangerang Selatan mempunyai batas administrasi sebagai berikut: (1) Sebelah Utara berbatasan dengan Kota Tangerang dan DKI Jakarta, (2) Sebelah Timur berbatasan dengan Provinsi Jawa Barat (Kota Depok) dan DKI Jakarta, (3) Sebelah Selatan berbatasan dengan Provinsi Jawa Barat (Kabupaten Bogor) dan Kota Depok, (4) Sebelah Barat berbatasan dengan Kabupaten Tangerang.

Pondok Aren merupakan kecamatan terluas di Kota Tangerang Selatan dengan luas 29,88 kilometer persegi sedangkan Setumerupakan kecamatan terkecil dengan luas 14,80 kilometer persegi (BPS Tangsel. 2018:3). Berdasarkan data tahun 2017, penduduk Kota Tangerang Selatan berjumlah 1,64 juta jiwa. 828.392 jiwa lakilaki dan 816.507 jiwa perempuan dengan sex ratio 101,52. Hal ini menandakan bahwa lebih banyak penduduk laki-laki dibandingkan dengan penduduk perempuan. 


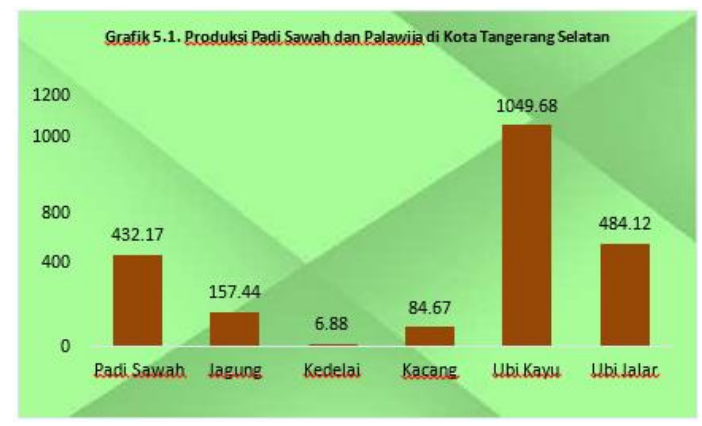

Grafik 1.1 (Sumber: Kota Tangerang Selatan dalam Angka hlm. 154)

Tangerang Selatan menghasilkan berbagai macam jenis pangan mulai dari hasil pertanian, perikanan dan peternakan. Dari grafik di atas menunjukan produksi Padi Sawah dan Palawijaya di Kota Tangerang Selatan dalam satuan Ton. Dalam grafik itu terdapat jenis pangan padi sawah, jagung, kedelai, kacang, ubi kayu dan ubi jalar. Dan yang mempunyai hasil panen terbesar dan berpotensi untuk dikembangkan adalah produksi ubi kayu dengan jumlah produksi seberat 1049, 68 ton.

Hasil-hasil pangan inilah yang nantinya akan di perjual belikan melalui pasarpasar yang tersebar di dalam daerah Tangerang Selatan maupun di luarnya. Dimana menurut grafik di bawah terdapat 13 pasar tradisional, 4 pasar perkulakan, 160 minimarket tempat trasaksi pangan. Data tidak termasuk dengan jumlah supermarket dan data akan terus berkembang.

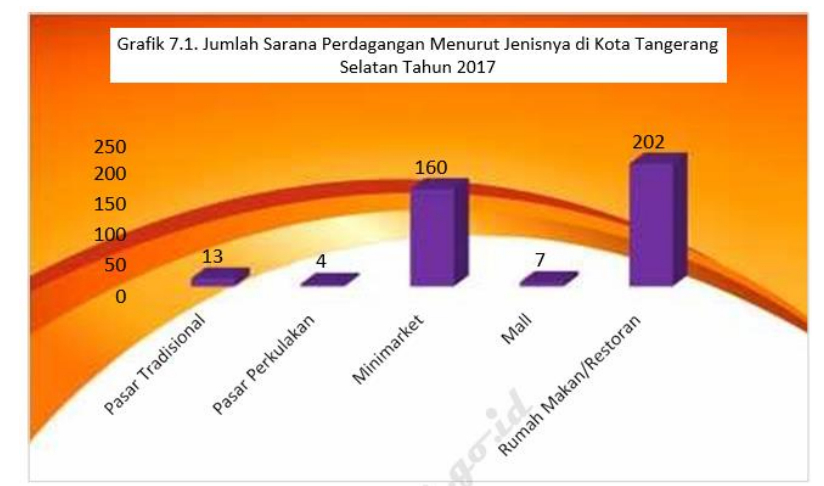

Grafik 1.2 (Sumber: Kota Tangerang Selatan dalam Angka hlm. 208)

\section{Kegunaan Bagi Masyarakat Sekitar}

Berdasarkan riset A. C. Nilsen (2003), jumlah konsumen yang membelanjakan uangnya di pasar modern kian meningkat. Pangsa pasar modern ini 
mencapai $26,3 \%$ di sisi lain jumlah toko tradisional mengalami penurunan sebanyak $8,1 \%$ per tahun. (Sulistyo. 2010: 561) data itu merupakan data beberapa tahun yang lalu, kemungkinan data tersebut jumlahnya sudah sangat meningkat.

Salah satu cara untuk menghidupkan eksistensi pasar tradisional di hati masyarakat adalah dengan adanya pasar tradisional yang dibungkus secara modern. Pasar-pasar semacam ini mulai banyak ada di Indonesia seperti di Jakarta, Balikpapan, dan juga salah satunya Tangerang Selatan. Pada khusunya kali ini kita akan membahas Pasar Segar Bintaro.

Menurut pak Toto, seorang staf administrasi yang saya wawancarai Pasar Segar Bintaro adalah pasar tradisional yang dikemas secara modern yang terletak di Kelurahan Pondok Jagung, Kecamatan Serpong Utara. Tanggerang Selatan. Sama seperti pasar pada umumnya pasar ini menjual berbagai kebutuhan sehari-hari masyarakat sekitarnya.

Kegunaan dari pasar ini adalah yang pertama sebagai wadah jual dan beli masyarakat kelurahan Pondok Jagung maupun masyarakat luar wilayah. Masyarakat dapat mencari nafkah dengan berjualan pangan-pangan yang berasal dari dalam ataupun luar wilayah kota Tangerang Selatan. Pangannya pun beraneka ragam dan penempatan lapak juga dikelompokan sesuai jenis pangan ada bagian buah dan sayur, rempah-rempah, kue basah, daging ikan, daging, sapi bahkan daging babi yang di tempatkan di tempat khusus. Dengan pengkategorian tempat dan kebersihan yang terorganisir dikarenakan ada staf yang selalu menjaga kenyamanan, kualitas pangan di Pasar Segar Bintaro dapat terjamin mutunya jika dibandingkan dengan pasar tradisional pada umunya.

Selain tempat berjualan, karena letaknya yang strategis didekat beberapa perkomplekan dan perkampungan pasar segar merupakan primadona masyarakat untuk berbelanja pangan. Karena bangunan yang luas juga beratap tinggi, dan kebersihan yang terjaga, pembeli tidak perlu khawatir dengan becek, berdesakdesakan dan kegerahan yang mana merupakan stereotipe pasar tradisional pada umumnya. 
Kegunaan yang tidak dapat kita pandang sebelah mata lainnya adalah, nilai budaya. Komunikasi yang terjalin antara pembeli dan penjual tidak dapat kita temukan di pasar modern, kegiatan tawar menawar merupakan saah satu komunikasi sekaligus budaya yang sudah turun temurun ada. Dalam pasar modern seperti minimarket harga barag sudah terpatok dan tidak bisa diganggu gugat. Sedangkan dalam pasar tradisional dalam masalah harga akan terjalin tawar menawar hingga terjadi kesepakatan win-win solution.

\section{Perbandingan Pasar Segar Bintaro dengan Pasar Tradisional dan Pasar Modern}

Pasar Segar merupkan pasar tradisional, namun terdapat banyak perbedaan Pasar Segar dengan pasar tradisional pada umumnya dan juga perbedaan Pasar Segar dengan pasar modern. Perbedaan pertama adalah dari segi fasilitas, dalam pasar segar disediakan parkiran, mushola, maupun toilet umum. Dalam pasar tradisional pun terdapat parkiran namun tata berantakan masih banyak orang yang suka memarkir kendaraan sembarangan, toiletnya pun seadanya dan tidak bersih.

Kedua adalah terorganisir, dalam pasar semacam Pasar Segar terdapat tatanan staf dan administrator yang jelas. Jenis pangan pasar pun dikategorikan sesuai dengan beberapa kategori tidak seperti pasar tradisional yang siapapun bisa berjualan di sudut kios manapun dengan berbagai macam dagangannya. Kebersihannya pun dijamin terjaga karena terdapat staf bagian kebersihan, hal ini tentu saja mendukung kualitas pangan yang ada di pasar tersebut.

Sama seperti pasar tradisional pada umumnya, Pasar Segar menjajakan sayuran yang segar dengan harga terjangkau jika dibandingkan dengan sayuran di supermarket yang relatif berharga tinggi.

Pasar segar yang terdiri dari berbagai lapak, kios, dan ruko yang dikelola secara pribadi, sehingga setiap kegiatan jual beli terdapat interaksi antara penjual dan pembeli yang bernilai budaya, tidak seperti pasar modern yang interaksi antara staf dan pembeli seminim mungkin dan kaku. 
Pengelolaan kios individu itu pula bisa mensejahterakan rakyat kecil, dimana masyarakat diberikan ruang berusaha kecil guna mencari nafkah, sedangkan pasar modern hanya dikelola oleh suatu badan perusahaan saja, rakyat kecil sulit terlibat di dalamnya.

\section{KESIMPULAN}

Pasar adalah pihak penjual dan pihak pembeli untuk melaksanakan transaksi dimana proses jual beli terbentuk. Terdapat pasar tradisional dan pasar modern sedangkan Pasar Segar Bintaro yang dibahas di makalah ini merupakan pasar tradisional yang dikamas secara lebih terorganisir. Terdapat banyak keebihan dan kekurangan pasar model seperti ini dibandingkan dengan pasar traadisional maupun pasar modern pada umumnya. Namun karena lebih banyak kelebihannya penulis harap pasar tradisional mulai banyak dikembangkan menjajadi pasar-pasar model seperti ini.

\section{DAFTAR PUSTAKA}

Arianty, Nel. 2013. Analisis Perbedaan Pasar Modern dan Pasar Tradisional Ditinjau dari Strategi Tata Letak dan Kualitas Pelayanan untuk Meningkatkan Posisi Tawar Pasar Tradisional [Online]. Tersedia: http://jurnal.umsu.ac.id/index.php/mbisnis/article/view/106/0. Diakses: 17 September 2018.

Badan Pusat Statistik Kota Tanggerang Selatan. 2018. Kota Tangerang Selatan dalam Angka 2018. BPS Kota Tangerang Selatan: Tangerang Selatan.

Mangeswuri, Restu, dkk. 2010. Revitalisasi Pasar Tradisional di Indonesia [Online]. Tersedia: http://jurnal.dpr.go.id/index.php/ekp/article/view/96. Diakses: 17 September 2018.

Rufaidah, Popy. 2018. Peran Teknologi Komunikasi dalam Rantai Nilai Pedagang di Pasar Tradisional [Online]. Tersedia: https://media.neliti.com/media/publications/41504-ID-peran-teknologi- 
komunikasi-dalam-rantai-nilai-pedagang-di-pasar-tradisional.pdf. Diakses: 17 September 2018.

Sulistyo, Heru. 2010. Model Penggembangan Pasar Menuju Pasar Sehat di Kota Semarang [Online]. Diakses: 17 September 2018.

.Dampak Operasi Pasar Modern Terhadap Pendapatan Pedagang Pasar Tradisional di Kota Pekalongan [Online]. Tersedia: https://unikal.ac.id/Journal/index.php/lppm/article/download/199/135. Diakses: 17 September 2018. 